gotowiem Opiekuńczym w Gdańsku w latach 1946-1989". Wystąpienie to m.in. przybliżyło zebranym trudności, na jakie natrafiają próby ustalenia dokładnej daty powstania Pogotowia Opiekuńczego w Gdańsku. O przeszłości gdańskiej placówki opiekuńczej mówiła także Pani Maria Biesiekierska, córka Anny Biesiekierskiej - osoby, która w latach 1950-1965 zarządzała Pogotowiem Opiekuńczym w Gdańsku. Pani M. Biesiekierska w wystąpieniu zatytułowanym „Wspomnienie o Annie Biesiekierskiej" nie tylko zaprezentowała postać swej matki i historię rodziny, ale omówiła także kilka problemów (dotykających sfery moralności i ideologii) związanych z codziennym kierowaniem placówką opiekuńczą w polskiej rzeczywistości doby PRL. Referat mgr G. Barczewskiego nt. „Pogotowie Opiekuńcze - dziś i jutro" przybliżył zebranym aktualne zadania placówki oraz główne problemy związane $\mathrm{z}$ ich realizacją. Prelegent w swoim wystąpieniu poruszył równieź kwestię zmian i tendencji rozwojowych w polityce opiekuńczej w Polsce i na terenie miasta Gdańska. Konferencję zamknęła prezentacja multimedialna „Dylematy 'wartości' w pracy z dzieckiem". Ten ponadczasowy problem w niebanalny sposób został opracowany przez: Marka Guzika, Małgorzatę Miłobęcką-Kamińską oraz Ewę Wilk - pracowników Pogotowia Opiekuńczego w Gdańsku.

Anna Paszkowska

\title{
Ogólnopolska Konferencja Naukowo-Metodyczna „Akademicka Burza Mózgów - czyli o aktywizujących metodach nauczania" historii wychowania, Gdańsk, 23-25 listopada 2007 roku
}

Początek XXI w., po okresie dynamicznego rozwoju szkolnictwa wyższego w Polsce lat 90. XX w., przyniósł w środowisku akademickim refleksje nad jakością oferty edukacyjnej. Problem ten mocno podkreślają również liczne dokumenty oświatowe o charakterze strategicznym. Wskazują one na konieczność szerszego zastosowania w procesie dydaktycznym metod aktywizujących. Zatem w szkolnictwie wyższym wypracowanie wysokiej jakości edukacji w znacznej mierze opierać się będzie na aktywnych, nowoczesnych metodach przeźywania oraz przekazywania wiedzy i wartości społecznych.

Wychodząc z tego założenia pracownicy Zakładu Historii Nauki, Oświaty i Wychowania oraz Koło Naukowe Historyków Edukacji Wydziału Nauk Społecznych Uniwersytetu Gdańskiego zorganizowali Ogólnopolską Konferencję Naukowo-Metodyczną pod hasłem „Akademicka burza mózgów - czyli o aktywizujących metodach nauczania”, która odbyła się dniach 23-25 listopada 2007 r. w Gdańsku.

To naukowe spotkanie, w myśl koncepcji organizatorów, w głównej swojej części przyjęło formę warsztatów. W związku z tym, liczba uczestników z góry została ograniczona do 20 osób. Warsztaty zgromadziły przedstawicieli nauki z 6 ośrodków naukowych w Polsce oraz aktywne grono studentek i absolwentek Uniwersytetu Gdańskiego.

Celem warsztatów było podjęcie dyskusji na temat metodyki nauczania historii wychowania w zakresie problematyki celów kształcenia we współczesnym szkolnictwie 
wyższym. Organizatorom chodziło nie tylko o wskazanie aktywizujących metod nauczania historii wychowania w odpowiedzi na aktualne potrzeby i możliwości kształcenia różnorodnych sprawności w procesie dydaktycznym, lecz także o wymianę doświadczeń nauczycieli akademickich w tym zakresie.

Otwarcia konferencji dokonał jej pomysłodawca i główny organizator mgr Mariusz Brodnicki. Zgromadzonych gości przywitał również prof. UG dr hab. Romuald Grzybowski, który życzył wszystkim owocnych obrad i niezapomnianych wrażeń z pobytu w Gdańsku.

Konferencja przebiegała w dwóch kompatybilnych płaszczyznach. W obszarze pierwszej z nich - teoretycznej - poruszono zagadnienia z zakresu aktywności i aktywizacji, założeń pedagogicznych oraz metodyki dociekań poznawczych. Problematykę tę w referacie pt. „Znaczenie materiałów w nauczaniu historii wychowania” przedstawił dr Robert Jankowski z Uniwersytetu Szczecińskiego. Autor w szczególności zajął się znaczeniem interpretacji tekstów źródłowych z historii wychowania oraz niezaprzeczalnej ich przydatności w działalności naukowej studentów. Natomiast mgr Monika Żmudzka w swoim wystąpieniu nt. „Wieloaspektowości problemu interpretacji” tekstu ukazała różnorodność i złożoność kwestii związanych z interpretacją tekstu historycznego w kontekście ponowoczesności. W tej części konferencji poruszono także aspekt nauczania historii wychowania w oparciu o materiał ikonograficzny. Interesujący ze względu na bogactwo materiałów źródłowych oraz refleksje dotyczące własnych doświadczeń w pracy dydaktycznej ze studentami okazał się referat dr Moniki Nawrot-Borowskiej z Uniwersytetu Kazimierza Wielkiego w Bydgoszczy pt. „Wykorzystywanie materiałów ikonograficznych w nauczaniu historii edukacji".

W drugiej płaszczyźnie tego spotkania naukowego jako dominującą przyjęto formę warsztatów. Zajęto się tu zatem aktywizującymi metodami nauczania. Uczestnicy zapoznali się z często wykorzystywaną w edukacji historycznej "metodą trybunału", która przygotowuje studentów do przeprowadzenia trudnych rozmów, zwłaszcza w zakresie aksjologii i konstruktywnego rozwiązywania problemów historycznych. Omówiona została również metoda „burzy mózgów”, ułatwiająca studentom twórcze rozwiązywanie problemów historycznych, a ponadto rozwijająca sprawność umysłową i wyzwalająca kreatywność. Zainteresowanie i duże zaangażowanie wśród uczestników wzbudziła szeroko stosowana we współczesnej dydaktyce ,metoda projektów”. Metoda ta zasługuje na uwagę, gdyż stwarza szczególne warunki do samodzielnego zdobywania wiedzy. Daje studentom możliwości formułowania problemu, organizowania fazy koncepcyjnej, a w końcu pełnej realizacji zadania. Ponadto uczestnicy warsztatów zapoznali się z wieloma innymi metodami aktywizującymi, np.: „,burzą pytań”, „metodą biograficzną", „metodą sytuacyjną", „metaplanem”, „linią czasu”. Na zakończenie części warsztatowej sekcja teatralna Koła Naukowego Historyków Edukacji wystawiła dramę zatytułowaną Przedstawienie o historii dzieciństwa.

Konferencję zakończyła dyskusja, która ujawniła duże zainteresowanie środowiska naukowego problematyką zaproponowaną przez organizatorów. W związku z tym zapowiedzieli oni kolejne, cykliczne spotkania naukowe poświęcone dydaktyce akademickiej. 